\title{
EFFECT OF DISTINCT PARAMETERS ON THE MECHANICAL PROPERTIES OF SOLID-STATE PROCESSED AA-2014
}

\author{
A. DEVARAJU*, M D. SAMEER, G. SAI KUMAR \& G. SRINU
}

Department of Mechanical Engineering, Kakatiya Institute of Technology \& Science-Warangal, Telangana State, India

\begin{abstract}
Solid state welding (FSW-Friction stir welding) is a new practice employed to join dis-similar and similar Aluminum alloys. FSW is a solid state joining process. Selection of materials and design have a profound impact on tool efficiency, weld quality and cost. Aluminum alloys with high resistance are commonly used in the aviation and marine industries. Mechanical properties of welded aluminum joints with fusion are usually weak. As friction stir welding occurs in solid state, no solidification structures are created eliminating the common fusion welding of high strength aluminum alloys in the brittle and eutectic phase.In this current paper a study has been carried out the effect of different parameters which affect on the mechanical properties of 2014 Al alloys processed by solid state processing technique which make the material suitable for various engineering applications. The parameters which shown maximum affects on the Aluminum alloy 2014 are considered as tool geometry, rotational speed, rapid cooling, cryogenic cooling, and formation of fine grain structure. By considering these parameters various mechanical properties are studied and analysed.
\end{abstract}

KEYWORDS: Al Alloy 20214, Cryogenic Cooling, Mechanical Properties, Solid State Welding

Received: Jun 10, 2020; Accepted: Jun 30, 2020; Published: Aug 01, 2020; Paper Id.: IJMPERDJUN2020555

\section{INTRODUCTION}

The Solid state welding is a method is used to weld the Aluminium alloys, which is invented by The Welding Institute (TWI), UK in 1991. A rotating and non-consumable welding tool is used in the FSW method to produce heat between the workpiece and the tool due to friction and causing deformation in the welding nugget region. FSW has extensive applications in the aviation, shipbuilding, automotive body building, and rail industries. Recently the critical studies have been studied on rotational velocity, travel speed, weld nugget, microstructure, mechanical properties and process parameters. Due to thermal expansion coefficient, high thermal conductivity, and shrinkages during the solidification process, the formation of the oxide layers in conventional welding process is significant. Oxide formation at weld nugget zone cannot be avoided after joining aluminum alloys using fusion joining technique and mechanical properties on the workpiece surface are also not improved. Solid state welding technique such as FSW is used for joining aluminum alloys to conquer this problem. However, FSW has persuaded benefits over conservative welding methods as it eliminates distortion, residual stresses in the welded nugget region. The ease of use of aluminium and its appropriate properties for industrial applications attracted the industries to utilize this material for various automobile, aerospace and other various manufacturing industries [1]. The properties like low density, light weight, good electrical conductivity, high corrosion resistant and low cost, made this material unique, attractive and most popular among the industries. Even though the material exists with attractive mechanical properties like ease in machinability still there exists drawbacks in welding this material with conventional welding techniques [1-2]. This situation draws the attention of researchers to come up with a new technique which can improve the microstructure and porosity of the weld zone. This resulted in developing a new 
technique which is known as solid-state joining process [3-4]. It was very difficult to join the Al alloys of $2 \mathrm{XXX}$ and 7XXX series with conventional welding techniques. The new process, solid state welding is developed and applied in joining these materials. The process works on the principle of rotation of tool pin on the base material which possesses the hardness greater than the parent metal. The rotational tool pin develops friction in between the tool and the parent metal which results in softening of that material below its melting point and produces superior weld joints. The rotational tool and the geometry of tool plays a significant role producing superior welds [5]. Apart from this the effect of cooling rates on the temperature generated during friction also considered as the important factors in achieving the superior welds [6-7]. Upon considering the above factors and their effect on the mechanical properties during solid state processing are analysed. However notable efforts have been made in the recent past to extend cost-effective and reusable tools, maximum efforts have been empirical in nature and further research is required to improve the geometry design of tools to advance FSW practice to hard and medium strength alloys [8-10]. This paper reviews critically recent research on many important aspects of FSW devices, such as device geometry, material selection problems, microstructure, load-bearing power, failure mechanisms, process parameters, and process economy.

\section{EXPERIMENTATION}

The two aluminium plates of length $210 \mathrm{~mm}, 60 \mathrm{~mm}$ width and $4 \mathrm{~mm}$ thickness are assembled together for welding by rotating tool pin on the plates. The rotating speed and traverse speed are controlled accordingly to achieve strong and smooth weld surface across the plates. Cooling agents are supplied continuously to maintain the temperature levels optimum without affecting the welding zone and the plates. Different types of cooling agents have shown different impact on the grain size and microstructure of the weld zone.

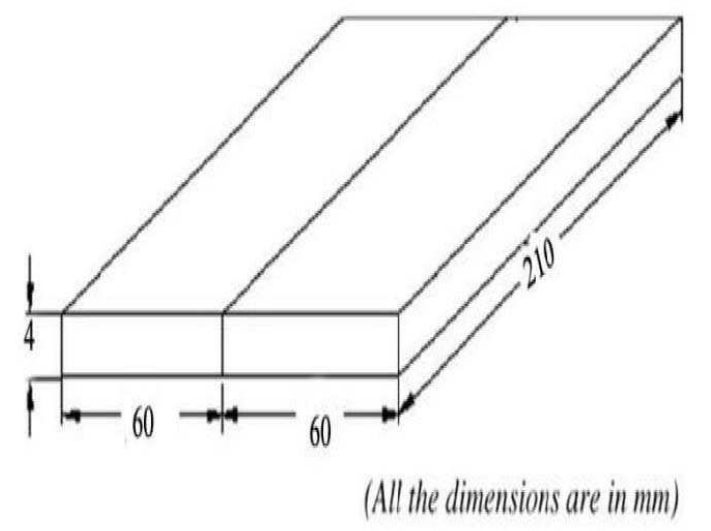

Figure 1: Schematic Sketch of Weld Joint and Tool. 


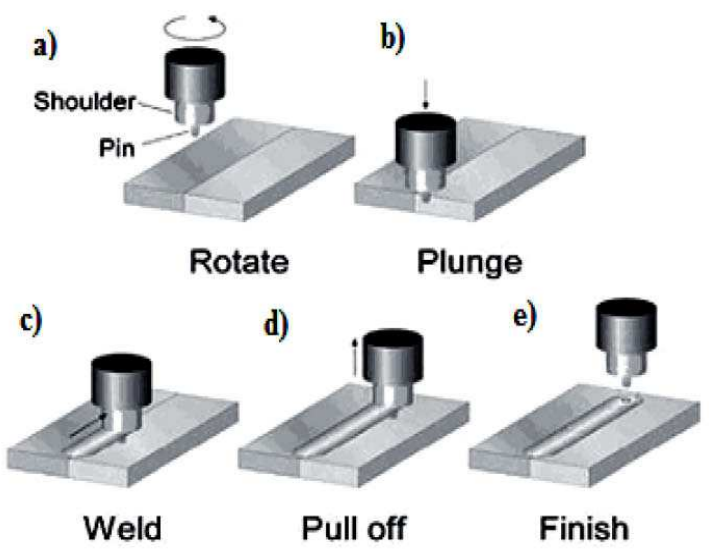

Figure 2: Schematic Sketch of Weld Configuration.

\section{RESULTS}

\section{Effect of Tool Geometry}

Tool pin profile and its rotating speeds and traverse speeds plays an important role in effecting the quality of weld and the mechanical properties of the welded aluminium plates. Two different tool pin interfaces are fabricated which are threaded straight cylindrical and threaded tapered cylindrical and three pin geometries are fabricated which are of radius 3,3.5,4 $\mathrm{mm}$. The tool pin is fabricated by using H13 standard steel tool. The shoulder diameter is given as $24 \mathrm{~mm}$ and pin length is given as $3.8 \mathrm{~mm}$. the process is carried out at $900 \mathrm{rpm}$ and $40 \mathrm{~mm} / \mathrm{min}$ feed rate with $2^{0}$ tilt angles are chosen.

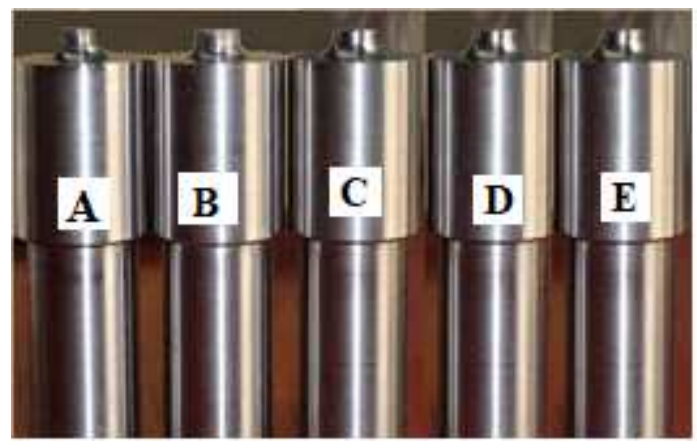

Figure 3: Fabricated FSW Tools.

\section{Tensile Properties}

The tensile properties of the samples prepared are carried out accordingly.

Table 1: Mechanical Properties Affected by Tool Pin Geometry

\begin{tabular}{|c|c|c|c|c|c|c|}
\hline S. No. & Tool Profile & $\begin{array}{c}\text { Yield Stress } \\
(\mathbf{M P a})\end{array}$ & $\begin{array}{c}\text { UTS } \\
(\mathbf{M P a})\end{array}$ & $\begin{array}{c}\text { \% of } \\
\text { Elongation }\end{array}$ & $\begin{array}{c}\text { Impact } \\
\text { Strength (J) }\end{array}$ & $\begin{array}{c}\text { Hardness } \\
(\mathbf{H v})\end{array}$ \\
\hline 1 & A & 266.48 & 325.25 & 3.56 & 3.0 & 124.15 \\
\hline 2 & B & 305.90 & 351.69 & 3.85 & 5.0 & 146.05 \\
\hline 3 & C & 89.70 & 135.99 & 1.28 & 4.0 & 122.16 \\
\hline 4 & D & 214.01 & 258.72 & 2.45 & 4.5 & 130.20 \\
\hline 5 & E & 254.80 & 304.37 & 2.87 & 3.0 & 129.80 \\
\hline
\end{tabular}




\section{HARDNESS PROPERTIES}

Vickers hardness is performed on the sample at nugget zone and it is observed that the hardness value is increasing progressively from heat affected zone to nugget zone. It is observed that shoulder of tool pin has a great impact on the properties of the weld plates. The hardness values are measured as $146 \mathrm{HV}$ highest values and $122 \mathrm{HV}$ as lowest value when used concave shoulder taper cylindrical threaded pin [11-13].

IMPACT PROPERTIES

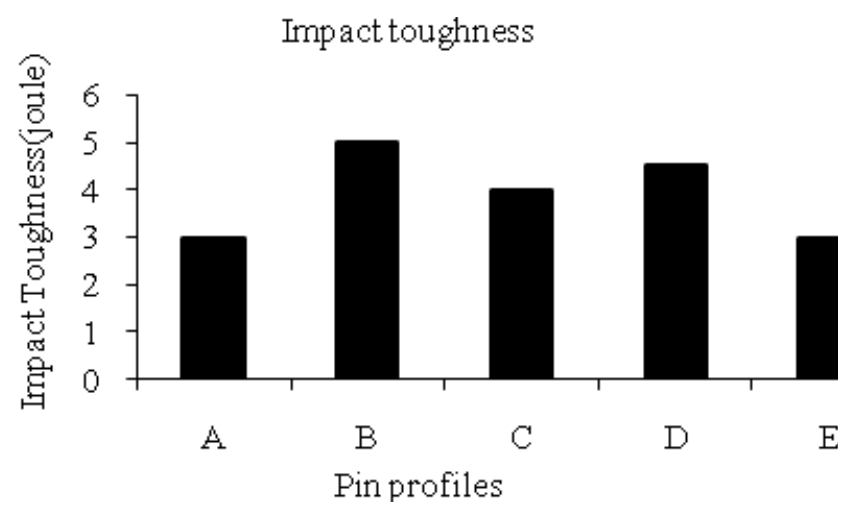

Figure 4: Impact Strength of Various Tool Profiles.

\section{EFFECT OF CRYOGENIC COOLING}

A cryogenic mixture of liquid nitrogen and dry ice are supplied continuously for solid state processing instrument for instant cooling. The effect of this cooling action shown some attractive results in the mechanical properties of the welded plates. The mechanical properties are observed at three different speeds such as 710,900,1400 with $40 \mathrm{~mm} / \mathrm{min}$ traverse speed [14-15].

Mechanical Properties

Table 2: Mechanical Properties Effected by Cryogenic Cooling

\begin{tabular}{|l|c|c|c|c|c|c|}
\hline \multirow{2}{*}{ Tool Profile } & $\begin{array}{c}\text { Rotational/Tranverse } \\
\text { Speed (mm/min) }\end{array}$ & $\begin{array}{c}\text { YS } \\
\left(\mathbf{N} / \mathbf{m m}^{\mathbf{2}}\right)\end{array}$ & $\begin{array}{c}\text { UTS } \\
\left(\mathbf{N} / \mathbf{m m}^{\mathbf{2}}\right)\end{array}$ & $\begin{array}{c}\text { \% of } \\
\text { Elongation }\end{array}$ & $\begin{array}{c}\text { Impact } \\
\text { Strength (Joule) }\end{array}$ & $\begin{array}{c}\text { Hardnes } \\
\mathbf{S}\end{array}$ \\
\hline \multirow{2}{*}{$\begin{array}{l}\text { Taper } \\
\text { Cylindrical } \\
\text { with threaded }\end{array}$} & $710 / 40$ & 266.48 & 325.25 & 3.56 & 03 & 124.15 \\
\cline { 2 - 7 } & $900 / 40$ & 305.90 & 351.69 & 3.85 & 05 & 146.05 \\
\hline
\end{tabular}

\section{EFFECT OF POST WELD RAPID COOLING}

Rapid cooling of the solid-state processed plates has a different impact on the mechanical properties when compared with cryogenic cooling. The properties observed are given below.

Table.3. Mechanical Properties Effected by Rapid Weld Cooling

\begin{tabular}{|l|c|c|c|c|c|}
\hline \multicolumn{1}{|c|}{ Samples } & $\begin{array}{c}\text { UTS } \\
\text { (Mpa) }\end{array}$ & $\begin{array}{c}\text { YS } \\
(\mathbf{M P a})\end{array}$ & \% El & $\begin{array}{c}\text { Microhardness } \\
\text { (Hv) }\end{array}$ & $\begin{array}{c}\text { Impact } \\
\text { Strength(J) }\end{array}$ \\
\hline Base Material & 483 & 414 & 13 & 138 & 13 \\
\hline $\begin{array}{l}\text { Taper with } \\
\text { Threaded }\end{array}$ & 552 & 483 & 18 & 164 & 08 \\
\hline
\end{tabular}




\section{CONCLUSIONS}

- It is clearly observed and concluded that the tool pin geometry had shown attractive impact on the mechanical properties.

- It is concluded that the tool pin with cylindrical taper threaded with $\mathrm{R}=3.5 \mathrm{~mm}$ have shown the highest mechanical properties when compared with base metal.

- Rapid cooling and cryogenic cooling shown noticeable improvement in the mechanical properties.

\section{ACKNOWLEDGMENT}

The author(s) would like to thank University Grants Commission (UGC) - New Delhi, Research Centre Imarat-Hyderabad and Defense Metallurgical Research Laboratory- Hyderabad for providing the facilities to carry out this work. Author, Dr. A. Devaraju is thankful to the Principal and Management of KITS, Warangal for their continuous support during this work

\section{REFERENCES}

1. R. S. Rana, Rajesh Purohit, S. Das. Reviews on the influences of alloy elements on the microstructure and mechanical properties of aluminum alloys and aluminum alloy composite. 2: 6: ISSN 2250-3153, 2012.

2. Mishra RS, Ma ZY. R 2005 Friction stir welding and processing. Mater Sci Eng; 50:1-78.

3. C.J. Dawes and W.M. Thomas, TWI Bulletin 6, p. 124, 1995.

4. Khan, MOHAMMAD ZAKIR HOSSAIN. "A case study on Occupational health and safety of footwear manufacturing industry." Journal of Business and GeneralManagement 2 (2017): 1-6.

5. Huseyin Uzun, Claudio Dalle Donne, Alberto Argagnotto, Tommaso Ghidini, Carla Gambaro. Friction stir welding of dissimilar Al 6013-T4 to X5CrNi18-10 stainless steel. 26 41-46, 2005.

6. De Filippis, P. Cavaliere. Influence of shoulder geometry on microstructure and mechanical properties of friction stir welded 6082 aluminum alloy. 28 1124-1129 8, 2007.

7. Huseyin Uzun, Claudio Dalle Donne, Alberto Argagnotto, Tommaso Ghidini, Carla Gambaro. Friction stir welding of dissimilar Al 6013-T4 to X5CrNi18-10 stainless steel. 26 41-46, 2005.

8. El-Shennawy, M., and Adel A. Omar. "Manufacturing of Nano/Micro Composites Using Friction Stir Processing." International Journal of Mechanical Engineering (IJME) 4. 3, Apr - May 2015, 29-48

9. M.K. Yadaya, R.S Mishra, Y.L.Chen, B. Carlson and G.J Grant: 'study of friction stir welding of thin aluminium sheets in lap joint configuration', Sci. Technol.weld.Joinn. ,2010,15,(1),70-75.

10. O. Lorrain, V. Favier, H. Zahrouni and D. Lawrjanice:' Understanding the material flow path of friction stir welding process using unthreaded tool, J. Mater. Process. echnol., 2010, 210,(4), pp 603- 609.

11. Chowdary, Undavalli Vivek, et al. "Home automation system using IR sensors." International Journal of Electrical and Electronics Engineering 4.6 (2015): 11-1.

12. J D.H. Choi, B. W. Ahn, C. Y. Lee, Y. M. Yeon, K.U. Song abd S.B. Jung; Effect of pin shapes on joint characteristics of friction stir spot welded AA5132 sheet. Mater. Trans., 2010, 5`, (5), pp.1028- 1032.

13. Sun, Y.F.; Fujii, H. The effect of SiC particles on the microstructure and mechanical properties of friction stir welded pure copper joints. Mater. Sci. Eng. A 2011, 528 (16-17), 5470-5475. 
14. Panneerselvam, K., and K. Lenin. "Study on hardness and micro structural characterization of the friction stir welded Nylon 6 plate." Int J Mech Eng, 2, 5162 (2013).

15. Scialpi, A.; Filippis, L.A.C.D.; Cavaliere, P. Influence of shoulder geometry on microstructure and mechanical properties of friction stir welded 6082 aluminium alloy. Mater. Des. 2007, 28 (4), 1124-1129.

16. L.Suvarna Raju,A. kumar and P nagabhara: In Proceedings of the International Conference on Cutting, Welding and Surfacing (CWS), Coimbatore, 22-23 Jan 2011.

17. Lee WB, Jung SB.The joint properties of copper by friction stir welding. Mater Lett 2004; 58: pp. $1041-1046$.

18. Harris D, Norman AF, prop of Friction Stir Welded joints: A review of the literature, E U POSTIR, program report presented at the 6th PSG meeting, 17-18 June 2003.

19. Park, HS.; Kimura, T.; Murakami, T.; Nagano, Y.; Nakata, K.; Ushio, M. Microstructures and mechanical properties of friction stir welds of 60\%Cu-40\%Zn copper alloy. Mater Sci Eng A 2004, 371 (1-2), 160-169. 